\title{
Case Study 2019; impact Of Pakistan And India War Conditions On Security Exchange Commission Of Pakistan
}

\author{
Aliya Tauqeer Islam \\ University of Management and Technology Lahore (UMT)
}

\begin{abstract}
This paper inspects the connection among FDI and fear based oppression, utilizing information from 2008 to 2018-19. The word 'Psychological oppression' is a term commonly used to depict the greatest potential degrees of ill-conceived deeds or compulsions where the greater part of the populace is influenced and the most noteworthy level of monetary action is upset. In any case, this isn't the last and concurred meaning of the word psychological oppression. There is no single meaning of psychological warfare which is worthy to all. Therefore, Pakistan has extraordinarily endured socially, monetarily, and politically also. Contrasting the advantages of the war and the expense caused, we can securely presume that the expenses are a lot higher than the advantages of this war against fear based oppression. Finding demonstrates that because of increment in the quantity of psychological militant assaults outside financial specialist indicating negative enthusiasm to put cash in Pakistan.
\end{abstract}

Keywords; FDI, Terrorism, SECP and Pakistan

\section{INTRODUCTION}

The world is very peaceful, till the peace haters distract the vision. The whole world is suffering from that kind of peace haters known as 'Terrorists'. Asia is a very useful and grown continent, without any disaster it seems beauty all around. The sub-continent Pakistan is also very fruitful country but the peace haters don't want its perfection. Pakistan is suffering from a high threat not only Pakistan but the whole world is confronting this disaster. The threat in a country wouldn't let anyone breath openly.

The terrorist attack creates hypo threat, tension, disaster, political instability, physical harm, economic instability, mental disorder and much more. The terror is an activity that only cause harm to the innocent people with bomb blasts, hijacks, kidnapping, harassments. The growth of a country depends upon a peaceful environment but that sudden attacks just ruin the whole budgetary system with the twinkling of an eye. The terrorists extreme vision is to destroy the humanity from the world and in their language they are cleaning the world by killing innocents. Terrorism not only create threat for the general public but it stops the economic and social growth of a country.

The people stop investing in such countries where number of attacks are higher. That create political and investment instability. The trades harm due to this, the imports and exports faces deficit even the foreign direct investments collapse. The foreign direct investment (FDI) is the source of investments from the foreign countries, where the enriched countries invest in developing countries to make them stable and in exchange they may be take some of useful commodities for their nations benefit. That's how the trade take place and investments increases. But eventually the attacks never let it happen. 
Sandler and Enders, (2005) define terrorism as the "the premeditated use or threat of use of violence by individuals or sub-national groups to obtain a political or social objective through the intimidation of a large audience, beyond that of the immediate victim". Many people have different opinions about terrorism influence on FDI. Some researcher's states that terrorism affects negatively on FDI. Gassebneret al (2005, p.7) composes that psychological oppressor assaults are probably going to have pessimistic and unfavorable outcomes on the venture conduct of the general population.

While others unmistakably attest that such exercises have nothing to do with the inflow of FDI to the nations concerned in light of the fact that venture choices are driven fundamentally by benefit and not by dread (Daniel Wagner 2006; Jackson, 2006). As indicated by Abadie and Gardeazabal, Javier's (2005) examination of FDI in Spain demonstrates a perpetual reduction in Spain's yield with the decay accomplishing more with a moving of financial exercises from the fear monger inclined districts to progressively verify locales.

Developing countries and underdeveloped countries have adverse effects of terrorism. The investors put their potential on that countries where they have the conformity of returns obviously everybody wants big piece of cake. FDI is one of the basic initiatives for a country. The whole matter depends upon the peace scale. FDI seems a type of support and trust that other country does. While the attacks make that trust weaker day by day so it's important for any country to maintain it.

\section{LITERATURE REVIEW}

As indicated by Abadie and Gandeazaba (2008), capital appropriation and capital speculations are antagonistically influenced because of psychological warfare, political shakiness and weakness. Alomar and El-Sakka (2011) expand connection among fear mongering and remote direct speculation with the assistance of 136 nations information. As per them, FDI inflows are contrarily influenced by psychological warfare. James et al. (2006) express that fear mongering put negative effect on remote direct speculation and monetary development. They further add that when contrasted with the open area associations, private part is exceedingly affected by psychological oppression exercises and political flimsiness. As per Gaibulloev and Sandler (2008) the main explanation behind negative effect on FDI is the loss of certainty by its financial specialists. Because of unsteadiness and uncertainty financial specialists take more weight and are dithered in capital venture choice in nations. Psychological warfare put negative effect on economy through diminishing inflow of FDI, devastation of foundation, cost caused on weakness, negative parity of installment (Bandyopadhyay, Sandler, and Younas, 2011). Evrensel and Kutan (2007) articulate fear based oppression as a mix of various exercises including political flimsiness, social turmoil, ethnic pressures, furnished clash, target slaughtering, clashes between various groups, and obstruction of various nations and so forth. Abadie and Gardeazabal (2008) contend that expansion in psychological warfare exercises results in capital flight. He further includes that a reduction in FDI builds the proportion of fear based oppression. Mihalache (2010) referenced that huge and negative effect of fear mongering on net FDI is watched particularly in mining, fabricating, development, transportation and system zones. Ali (2010) explains the effects of mental fighting in Pakistan as obliteration of establishment, low earnings, capital flight, loss of employment, declining of development rates, the travel industry decrease in northern pieces of Pakistan and henceforth the weakening of by and large economy. Fear based oppression has likewise its effect on macroeconomic factors, GDP, expansion and joblessness (Ismail and Amjad, 2014). Most research studies exhibit that much centrality has been given to FDI as it is considered as a huge instrument for survival, improvement and strength of country. Alomar et al., (2011) recognizes the Importance of FDI as it isn't just a wellspring of capital inflow yet additionally a wellspring 
of innovation, mastery, salary and market access to the nations. Shahbaz et al. (2012) directed an examination to explore the connection between the FDI inflows and fear mongering in Pakistan. As indicated by the aftereffect of concentrate noteworthy negative effect of fear mongering on outside direct speculation is watched. As per Rasheed and Tahir (2012) fear based oppression makes uncertainty in a nation that eventually results in the loss of outside financial specialist certainty that prompts decline in remote direct venture. As per Hyder et al. (2015), Pakistan is confronting the outcome of Afghan War; and faces the issues of diminishing remote direct speculation because of different religious clashes that are improving the fear based oppressor exercises. He further shows that fear mongering is the significant obstacle in inflow of FDI. Bandyopadhyay et al. (2014) reports the relationship among FDI and psychological oppression. In this investigation information in regards to seventy-eight immature nations from 1984-2008 is gathered. As per them huge connection between the FDI and psychological oppression is watched however remote guide brings FDI. Agrawal (2011) makes reference to critical negative relationship between the FDI and psychological warfare found in immature nations, with exceptional effect of FDI in assembling, exchange, fix and development divisions.

\section{RESEARCH METHODOLOGY}

The point of the paper is to survey the effect of fear based oppression on the FDI of Pakistan. The nation's advancement relies on the components; these variables incorporates Foreign Direct Investment (FDI), fabricating, transport, correspondence, political soundness and significantly more. Further the upgrade of these segments likewise relies upon certain variables. Along these lines, the important information and data have been gathered from different sources. These sources incorporate Global Terrorism Database (GTD), Global Terrorism Index (GTI), Trading Economics (Pakistan Terrorism Index) and Pakistan Stock Exchange (PSX). The information is as tables and diagrams for the better understanding and after that ends have been drawn. The paper utilized illustrative procedure to make investigation of the gathered information from different national and worldwide sources.

\section{Comparison of Past Events:}

The terrorism of Pakistan has been spreading terror since the creation of this great nation but in this paper the data is regarding past 10-15 years. In 2008 the drone attacks in Pakistan caused 33 incidents in which 313 people killed and 17 were injured.

In 2010 the ratio of attacks calculated by average that was 8.61. in 2012 the average got increased by 8.86, in 2013-14 the again increase in terrorism but their averages remain same in these two years that was 9.07, in 2015 the slow decrease occur in terror attacks and in 2016 the ratio becomes 8.40, in 2017 the ratio now on decreasing point that is 8.18 and in 2018 its 8.0. Fear based oppression Index in Pakistan diminished to 8.18 in 2017 from 8.40 in 2016. Psychological warfare File in Pakistan touched base at the midpoint of 7.89 from 2002 until 2017, accomplishing a record-breaking high of 9.07 in 2013 and a record low of 6.12 in 2003. 


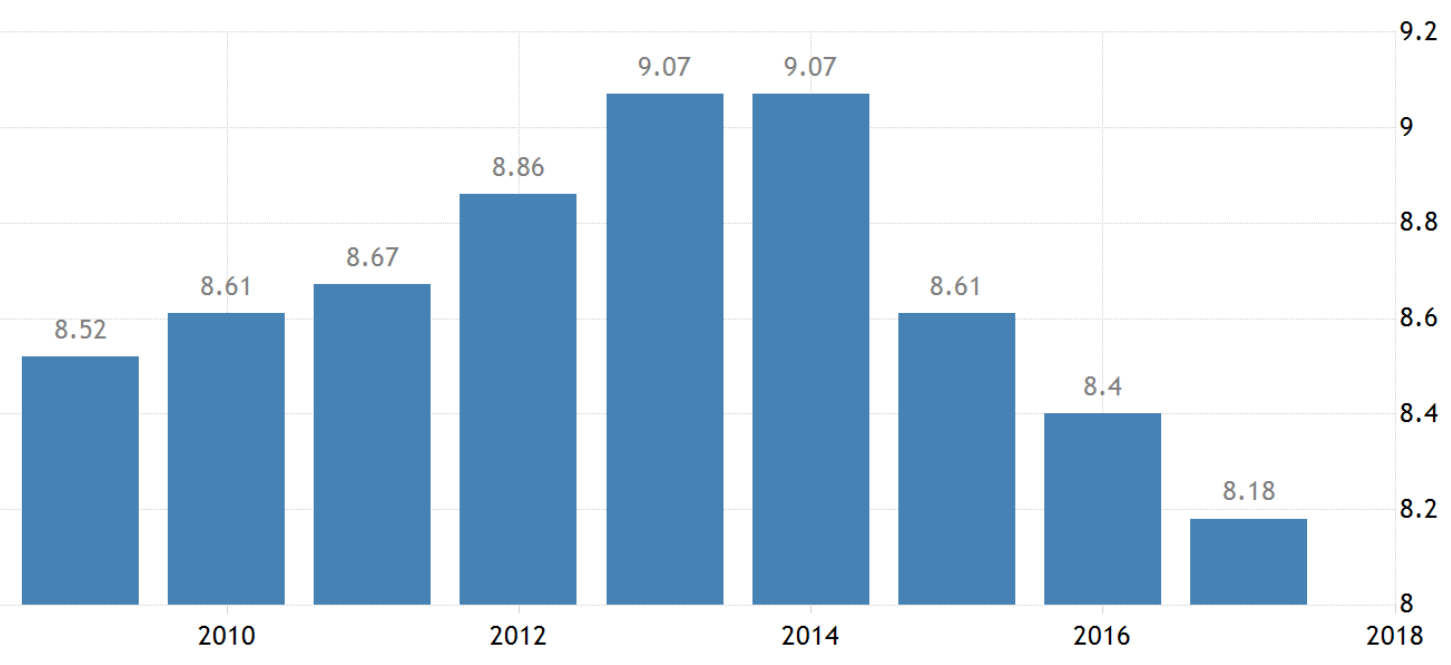

SOURCE: TRADINGECONOMICS.COM I INSTITUTE FOR ECONOMICS AND PEACE

Psychological oppression during past decade and a half has negatively affected Pakistan as in excess of 63,000 individuals lost their lives up until this point. Fear mongering in Pakistan has turned into a noteworthy wonder from the previous decade, generally declining during late couple of years. 62,096 are the quantity of fatalities from psychological oppressor assaults from 2003 to 2017 and 5,303 is the quantity of killed individuals on partisan premise from 1989 to 2017. Other than this current, Pakistan's 'war on fear' has cost \$118 billion up until now, a report by the State Bank uncovered in Nov 2016. The State Bank of Pakistan (SBP) in its yearly report demonstrated that radical brutality cost the nation $\$ 118.3 \mathrm{bn}$ in immediate and backhanded misfortunes from 2002 to 2016.

\section{"Both economic growth and social sector development have been severely hampered} by terrorism-related incidents," the report said.

It merits referencing here that the Pakistan's net open obligation has crossed the Rs18.28 trillion imprint, ascending about 35pc during the residency of the decision Pakistan Muslim League-Nawaz (PML-N). Inquisitively, \$118.3 billion, which Pakistan spent on 'war on fear', were sufficient to pay the all-out advance of Pakistan, in the event that they were not spent to free of the hazard of dread from nation in recent years. Each Pakistani owes over Rs115,000 as the nation's heap of complete obligation and liabilities expanded to PRs 23.14 trillion before the finish of December 31, 2016, a year-on-year increment of 10pc, as per temporary figures refreshed by the State Bank of Pakistan (SBP).

In different suicide besieging assaults in the initial five months of 2017, 599 individuals have been passed on up until this point. An aggregate of 256 regular folks included 38 in Jan, 114 in Feb, 26 in March, 28 in April and 50 in May this year. 71 faculty of security powers included 9 in Jan, 23 in Feb, 19 in March, 16 in April and 4 in May. 272 psychological militants have been additionally got murdered included 14 in Jan, 125 in Feb, 62 in March, 63 in April and 8 in May up until this point. It is noticed that partisan executing in Pakistan is likewise another enormous issue. As indicated by the official record, accessible with Pakistan Today, 5,303 separate individuals were killed in 3,045 partisan episodes which likewise leaves 9,974 individuals harmed. As indicated by information, imparted to Pakistan Today, 78 individuals were killed and 71 harmed in 29 occurrences in 2016. In 2015, 276 murdered and 327 harmed in 53 assaults. In 2014, 208 murdered and 312 harmed in 91 partisan slaughtering occurrences from 1989 to 2016. In 2013, 558 individuals were killed and 987 harmed in 131 episodes. In 
2012, 507 passed on and 577 harmed in 173 episodes. In 2011, 203 killed and 297 got harmed in 30 occurrences. In 2010, 509 individuals lost lives and 1170 were harmed in 57 partisan based assaults. In 2009, 190 got murdered and 398 got wounds in 106 occurrences. In 2008, 306 individuals were killed and 505 were harmed in 97 episodes. In 2007, 441 got executed and 630 got wounds in 341 occurrences. In 2006, 201 got executed and 349 got wounds in 38 episodes. In 2005, 160 individuals were killed and 354 harmed in 62 episodes. In 2004, 187 killed and 619 got harmed in 19 episodes. In 2003, 102 killed and 103 got harmed in 22 episodes. In 2002, 121 killed and 257 got harmed in 63 episodes. In 2001 post-9/11, 261 individuals lost their lives while 495 were got wounds in 154 assaults. In 2000, 149 individuals were slaughtered in 109 assaults. In 1999, 86 murdered and 189 harmed in 103 episodes. In 1998, 157 slaughtered and 231 harmed in 188 partisan assaults. In 1997, 193 slaughtered and 219 harmed in 103 assaults. In 1996, 86 individuals killed and 168 harmed in 80 assaults. In 1995, 59 executed and 189 harmed in 88 assaults. In 1994, 73 individuals killed and 326 got wounds in 162 assaults. In 1993, 39 individuals slaughtered and 247 harmed in 90 assaults. In 1992, 58 individuals were killed and 261 got wounds in 135 occurrences. In 1991, 47 individuals slaughtered and 263 got harmed in 180 assaults. In 1990, 32 individuals were exposed to kill on partisan premise in 274 occurrences which likewise leaves 328 individuals harmed, and in 1989, 18 individuals murdered and 102 harmed in 67 assaults.

\section{Source: pakistantoday.com.pk}

\section{Overview of Terrorist Attacks in Pakistan:}

A long time examined in this information are 2002 to 2015: According to GTD, there are in excess of 10,000 psychological militant assaults in Pakistan with minimal more than 18,000 individuals were killed and in excess of 30,000 injured. It would seem that whole Pakistan is affected which is very obvious yet the greater part of the assaults did in Baluchistan, FATA and KPK. These three areas lie on the fringe with Afghanistan!

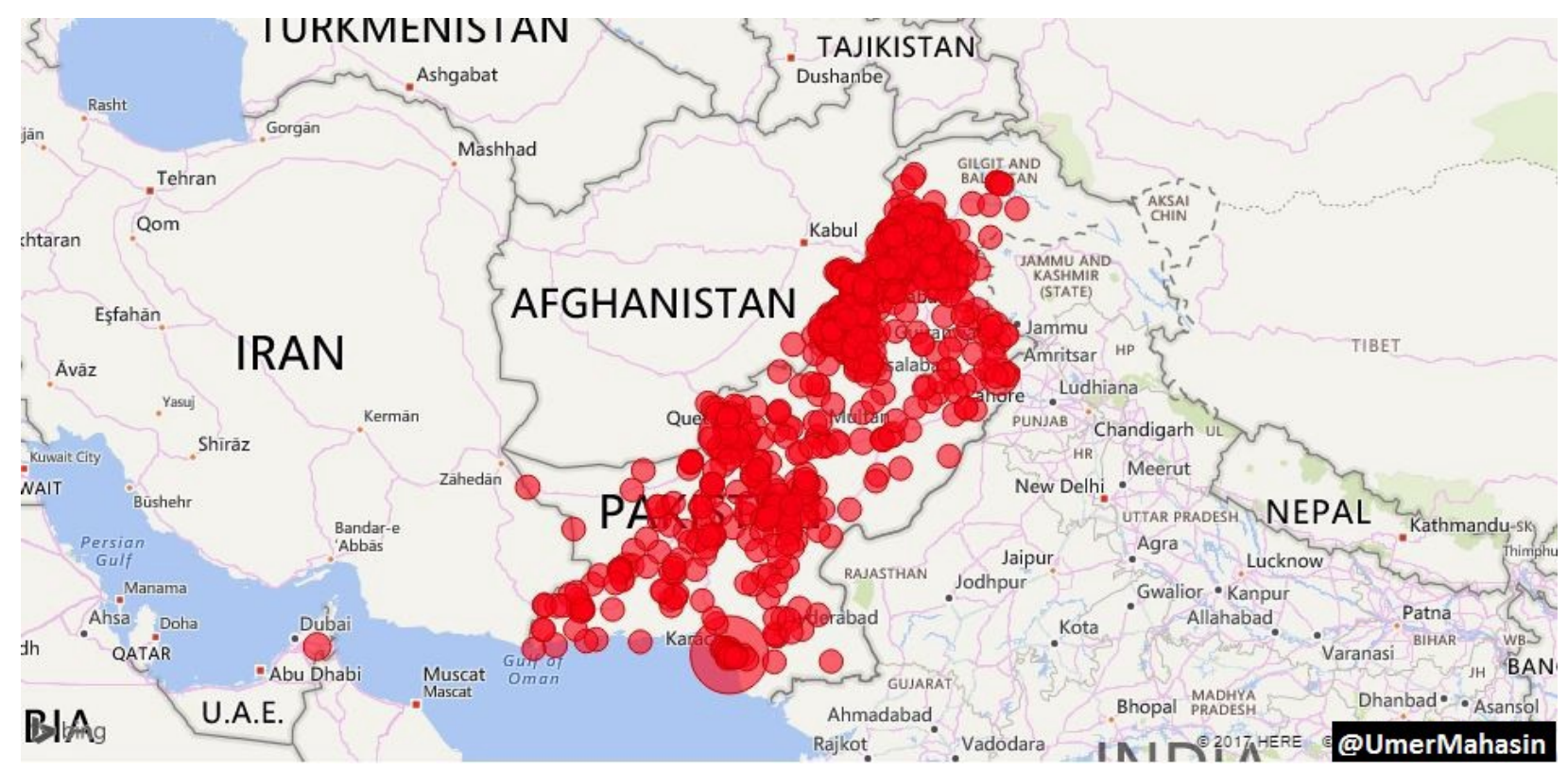




\section{Overview of Terrorist Attacks in India:}

That is the manner by which the psychological militant assaults in India looks like on a guide.

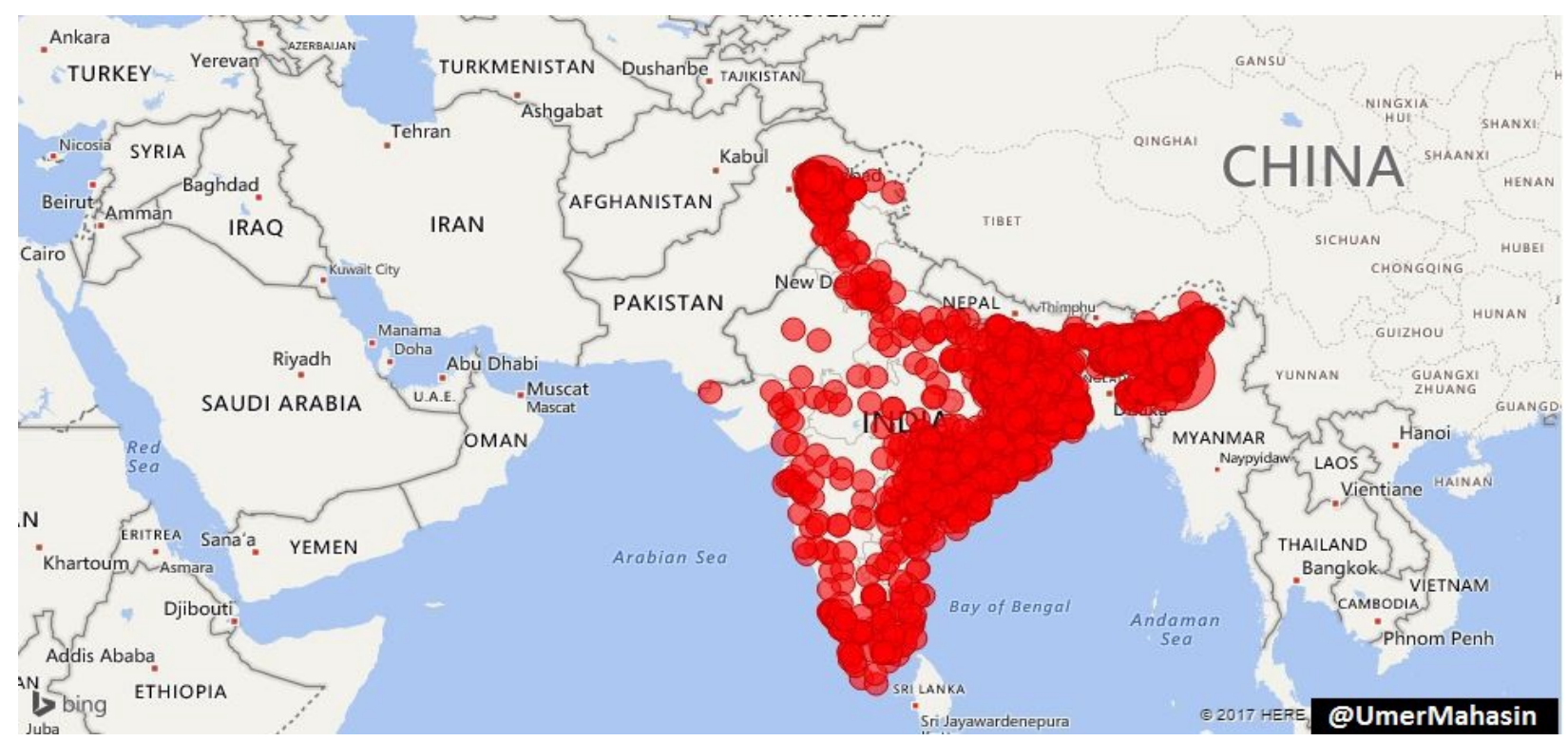

It begins from Kashmir and goes further in East, South, North and South-East India. In the event that Pakistan is sending out psychological warfare in India, for what reason don't we see any action over the 2900+ KM fringe? Why just Kashmir experiences difficulty? Since it's a contested region between India and Pakistan and individuals of Kashmir battling their war of opportunity which has additionally been incorporated as psychological warfare in GTD database. As indicated by GTD, 6488 fear based oppressor assaults were recorded in India during 2002-2015. Minimal in excess of 7600 individuals executed and more than 14400 injured. 329 assaults were completed by "Islamic" bunches perpetrated 1119 causalities in most recent 15 years while the rest goes to the "non-Islamic" gatherings. As should be obvious underneath, over 95\% of assaults by "Islamic Groups" were in Kashmir, once more, questioned zone with dynamic opportunity development.

\section{Source: towardsdatascience.com}

\section{Variations in Stock Market:}

This data is collected by the average range of last 5 years the most relevant variations can also be seeing by the official website given below.

$34,739.2779 .42(0.23 \%)$

As of Jun 12, 2019 2:24 PM

\section{OPEN}

34,617.62

\section{PREVIOUS CLOSE}

34,659.85

VOLUME

88,515,920

\section{1-YEAR CHANGE}

$-20.31 \%$

YTD CHANGE

$-8.57 \%$

\section{DAY RANGE}

34,607.71 - 35,137.56

52-WEEK RANGE

$32,352.40-44,332.86$ 


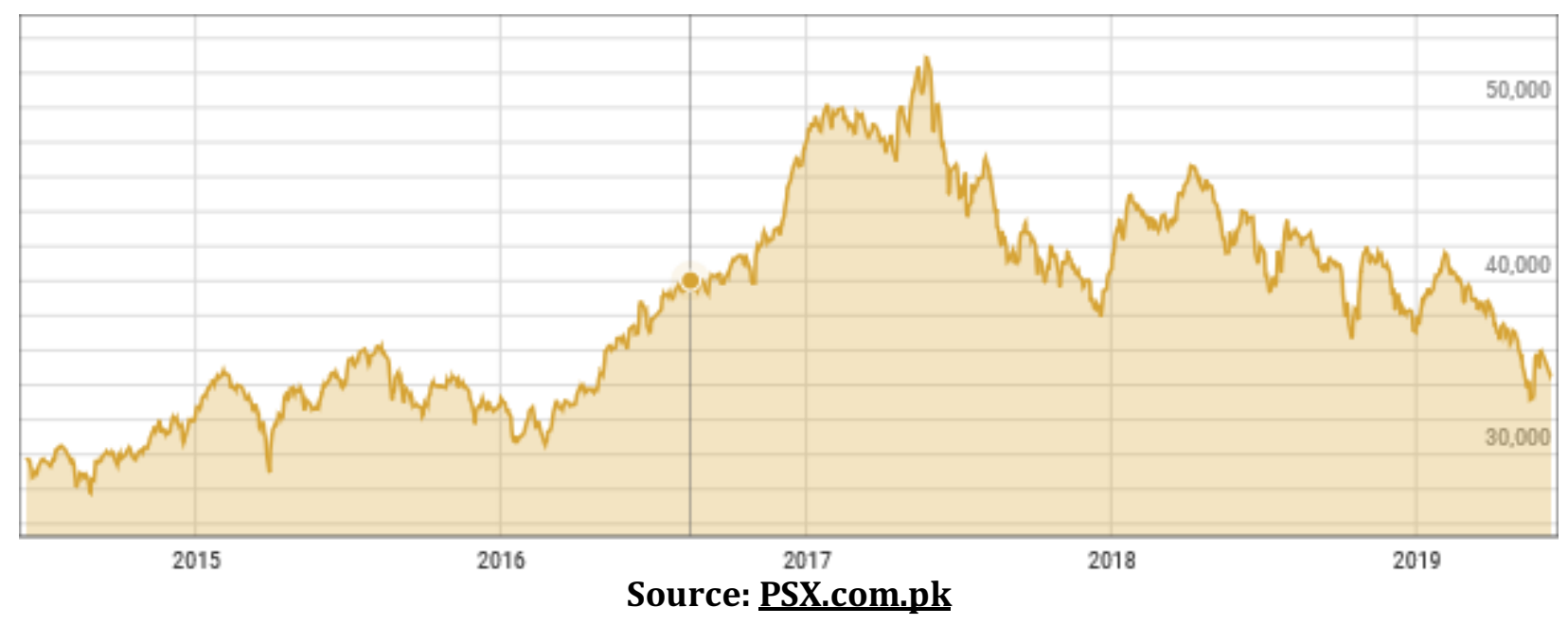

\section{Indo-Pak Stock Market Clashes:}

In the wake of losing 785 points on Tuesday over rising pressure between New Delhi and Islamabad, the KSE-100 of the Karachi Stock Exchange shed 275 on Wednesday as strains keep on raising between the two neighbors. The KSE-100 of the Karachi Stock Exchange on Wednesday broadened misfortunes in the wake of rising pressure among India and Pakistan. In the wake of losing 785 points on Tuesday over rising pressure between New Delhi and Islamabad, the KSE-100 of the Karachi Stock Exchange shed 275 on Wednesday as strains keep on heightening between the two neighbors. Market specialists said this is the biggest shock that has struck the Pakistani markets in most recent 55 days of exchanging. They further said that benchmark KSE-100 had dipped under 39,000 points without precedent for 32 exchange sessions. As indicated by specialists, the market endured after Inter-Services Public Relations (ISPR) and Pakistan affirmed reports of Indian airstrikes over the Line of Control (LoC). A business house affirmed that Pakistani markets endured immense misfortunes because of increased strain. In the interim, Indian markets have additionally been jittery since yesterday over heightened pressure between the two countries. While benchmark records opened on a higher note in the wake of shutting 239 points lower on Tuesday, BSE Sensex bounced back 256 points toward the beginning of the day. Notwithstanding, at the season of composing this article, it was exchanging red; Nifty, as well, was somewhere around 40 points. In spite of the fact that the unpredictability in the financial exchange enables speculators to investigate choices, specialists showed the likelihood of ascending close term hazard because of a circumstance of high caution in the wake of the present infringement by Pakistan. Multi day after India disposed of a Jaish fear camp on Jabba Top, situated on some backwoods close Balakot in Pakistan, the neighboring country's aviation based armed forces ruptured the Line of Control on Wednesday. Pakistan asserted it has shot down two Indian planes and arrested one IAF pilot. India, as well, said it had shot down a Pakistan F-16 in the present elevated clash. In the outcome of the present scene, both the countries have suspended flight tasks at certain airplane terminals. India has closed down flights to eight areas including Jammu and Srinagar. The Indian Air Force has put every one of its bases on "most elevated caution" while Pakistan appears to have suspended flight activities in the entirety of its air terminals.

\section{Source: indiatoday.in.hesitant.com}




\section{Foreign Direct Investment (A Short Analysis from Past):}

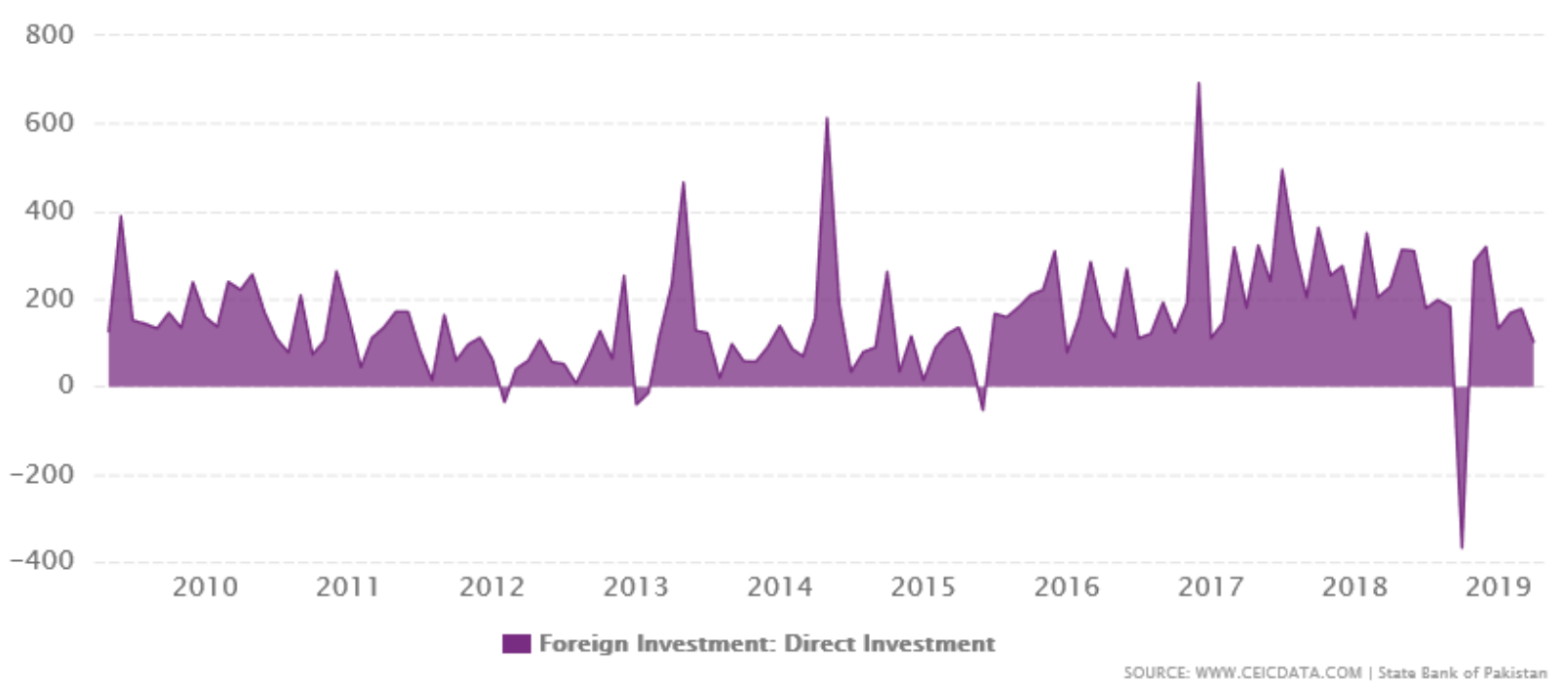

Source: CIECDATA.COM | STATE BANK OF PAKISTAN

In the $1^{\text {st }}$ section of 2010 the FDI is slightly decreasing due to terrorist attacks but in 2017 it started increasing due to less attacks, in 2018 there is another slight decrease in the FDI. These changes show the negative relation in terrorism and FDI. The results have been drawn from the secondary data.

$\begin{array}{llllll}\text { Pakistan Markets } & \text { Last } & \text { Previous } & \text { Highest } & \text { Lowest } & \text { Unit } \\ \text { Currency } & 150.90 & 150.80 & 151.75 & 18.60 & \\ \text { Stock Market } & 34756.30 & 34659.85 & 52876.46 & 538.89 & \text { points } \\ \text { Government Bond 10Y } & 14.14 & 14.14 & 16.65 & 4.17 & \text { percent }\end{array}$

The USDPKR expanded 0.1000 or $0.07 \%$ to 150.9000 on Wednesday June 12 from 150.8000 in the past trading session. For the most part, the Pakistan Rupee accomplished a superb high of 151.75 in May of 2019 and a record low of 18.60 in December of 1988.

Source: TRADINGECONOMICS.COM | INSTITUDE FOR ECONOMICS AND PEACE

\section{CONCLUSION}

It is really clear that the terrorism affected Pakistan's economy, growth, investment, FDI, and agriculture even every single thing is got influenced by terrorism. What the progressing war on dread has given to Pakistan, Haq and Hussain (2008, pp.82-83) writes in these words:

"The war on terror has only prompted terror and militancy. It has affected new areas and expand in the scope and breadth including indoctrinating those who were on the sidelines. The collateral damage has affected thousands of innocent families driving them in to the lap of insurgency. It has helped bartered away Pakistani sovereignty and has been a huge humiliation to its 160 million people."

According to the findings, indicates that there is a negative relation between FDI and terrorism. People show less confidence while investing in a terrorist country. People use to invest in that kind of country where they have full confidence of paid back. Fear mongering aggravates by and large economy and business condition of a nation which results in instability for remote speculators and hinders the business exercises.

The approach producers should consolidate procedures for certainty working of outside financial specialists while their encircling their arrangement outlines. The results are concrete 
and clear with the negative slops the graphs will help in understanding of every individual's prospect mean while the descriptive data will enhance the knowledge.

\section{Reference:}

Abadie, \& Gandeazaba. (2008). The economic costs of conflicts: A case study of the Basque country. The American Economic Review, 93, 113-132.

Abadie, Alberto and Gardeazabal, Javier (2008) "Terrorism and the World Economy".

Agrawal, S. (2011). The impact of Terrorism on Foreign Direct Investment: Which Sectors Are More Vulnerable. CMC College,

Ali, Arshad (2010) Socio-Economic Costs of Terrorism: A Case Study of Pakistan. Pakistan Security Research Unit, Brief Number 57.

Economic Surveys (2006-07 and 2010-11) Ministry of Finance Islamabad, Finance Division.

Gassebner, M.A; Keck, A. and The, R. (2005) The Impact of Disaster and Terrorism on International Trade. WTO Working Paper.

Haq, Noor-ul and Hussain, Khalid (2008) Pakistan: A Victim of Terrorism, volume 1, Islamabad Policy Research Institute (IPRI), Fact file.

Sandler, Todd and Walter Enders (2005). Economic Consequences of Terrorism in Developed and Developing countries: An Overview Downloaded on 6 November 2010. Retrieved from: http://www.cba.ua.edu/ wendors Econ Consequences Rivised.pdf.

Tarzi. (2005). Foreign direct investment flows into developing countries: Impact of location and government policy. The Journal of Social, Political and Economic Studies, 4, 497-515.

Tavares. (2003, November 21-22). The economic cost of terrorism. 